\title{
Effect of Vegetable Oils in Growth of Lactococcus garvieae Isolated from Palm Oil-contaminated Soil and Its Lipase Production
}

\author{
S Sumarsih ${ }^{1}$, S Hadi $^{1}$, Fatimah ${ }^{2}$, SL Bayasud ${ }^{1}$ \\ ${ }^{1}$ Chemistry Department, Faculty of Sciences and Technology Universitas Airlangga \\ Kampus C Unair Mulyorejo Surabaya. \\ ${ }^{2}$ Biology Departement, Faculty of Sciences and Technology Universitas Airlangga Kampus C Unair \\ Mulyorejo Surabaya. \\ *Corresponding author.Email:: sri-sumarsih@fst.unair.ac.id
}

\begin{abstract}
This research aims to study the effect of vegetable oils in the growth of of Lactococcus garvieae isolated from palm oil-contaminated soil and its active lipase production. The bacteria was grown in medium containing minerals and vegetable oils (virgin olive oil, virgin coconut oil, mustard oil and sunflower oil) as sole carbon sources. The bacteria growth was measured as optical density at $\lambda=600 \mathrm{~nm}$. The lipase production was determined as lipase activity of crude extract toward $\rho$-nitrophenyl palmitate as a substrate. The results showed that the vegetable oils used provided the good growth and lipase production of L.garvieae. Even though, olive oil had a great inductive effect on bacterial productivity. The addition of $1 \%$ olive oil improved the lipase activity by $135 \%$ compared to without olive oil. Crude extract with lipase activity of $56.790-66.571 \mathrm{U} / \mathrm{mL}$ produced by L. garvieae when cultivated in medium containing $1-5 \%$ olive oil for 20 hours. Electrophoregram of SDS PAGE and zymographic analysis showed that there were 2 types of lipases produced by L. garvieae, as indicated by the presence of protein bands around 85 and $45 \mathrm{kDa}$.
\end{abstract}

Keywords: Lactococcus garvieae, palm oil, Lipase.

\section{INTRODUCTION}

Increasing interest in lipases due to their potential application, in (bio)degradation as well as in (bio)synthesis of glycerides. The advantages of the enzymatic hydrolysis over the chemical process consist of less energy requirements and higher quality of the obtained products. Beside this, lipases are also efficient in various reactions such as esterification, transesterification and aminolysis in organic solvents. Lipases are widely used in many industries: food industry [1], detergent [2], flavors [3], cheese [4], pulp and paper, leather, textile, cosmetic, pharmaceutical, biodiesel production [5]. Lipases are also used in organic synthesis, bioconversion in aqueous/ organic media, resolution of racemic mixture, regioselective acylation, and ester synthesis [6]. Lipases are produced by various plants, animals, and microorganisms. Lipolytic microorganisms have been found in diverse habitats such as industrial waste, vegetables oil processing factories, dairies, soil contaminated with oil, oilseeds, and decaying food, compost, hot springs, and other habitats [6]. Considering the wide application of lipases in various industries and organic synthesis, several studies were conducted for potential lipaseproducer microorganisms, novel enzymes from new sources with unique properties. In the previous study, a lipolytic bacteria Lactococcus garvieae has been isolated from palm oil mill effluentcontaminated soil [7]. Lipase production is influenced by the type and concentration of carbon and nitrogen sources, the culture $\mathrm{pH}$, the growth temperature, and the dissolved oxygen concentration. This present paper focuses on the effect of vegetable oils on bacterial growth of Lactococcus garvieae strain L49 and its lipase production.

\section{MATERIALS AND METHODS}

\subsection{Microorganism}

Bacteria used in this study was a lipolytic bacteria Lactococcus garvieae strain L49 isolated from palm oil-contaminated soil. The bacteria was periodically sub-cultured in Luria Bertani (LB) medium. 


\subsection{Chemicals and medium composition}

All of the chemicals used were analytical grade. LB medium consisted of (w/v): $1 \%$ tryptone, $0.5 \%$ yeast extract, $1 \% \mathrm{NaCl}$, and $2 \%$ bacto agar used for bacterial rejuvenation and pre-cultured preparation.The medium used for the lipase production was modified medium containing 12 $\mathrm{g} / \mathrm{L} \quad \mathrm{Na}_{2} \mathrm{HPO}_{4}, \quad 2 \mathrm{~g} / \mathrm{L} \quad \mathrm{KH}_{2} \mathrm{PO}_{4}, \quad 0.3 \quad \mathrm{~g} / \mathrm{L}$ $\mathrm{MgSO}_{4} .7 \mathrm{H}_{2} \mathrm{O}, 0.25 \mathrm{~g} / \mathrm{L} \mathrm{CaCl} 2,20 \mathrm{~g} / \mathrm{L}\left(\mathrm{NH}_{4}\right)_{2} \mathrm{SO}_{4}$ and $2 \%(\mathrm{v} / \mathrm{v})$ vegetables oil. The source of nitrogen $\left(\mathrm{NH}_{4}\right)_{2} \mathrm{SO}_{4}$ was varied with urea and peptone. Vegetables oil includes virgin olive oil, virgin coconut oil, mustard oil and sunflower oil are used as main carbon sources.

\subsection{Effect of vegetable oils on bacterial growth and lipase production}

The effect of vegetable oils as carbon sources on the bacterial growth and lipase production of Lactococcus garvieae strain L49 was studied by cultivating the bacterial cell in the medium containing various vegetable oils (olive oil, coconut oil, mustard oil and sunflower oil). Overnight bacterial culture $\left(\mathrm{OD}_{600}=0.5\right)$ were inoculated to $500 \mathrm{~mL}$ flasks containing $100 \mathrm{~mL}$ of production medium and incubated at $37^{\circ} \mathrm{C}$ on shaker incubator $150 \mathrm{rpm}$. The bacterial growth and lipase production were monitored every 4 hours. Bacterial growth was observed by measuring the optical density using spectrophotometer UV/Vis at $\lambda=600$ $\mathrm{nm}$. Enzyme production was observed based on the lipase activity of the enzymes produced. The lipase activity was determined toward $p$-nitrophenyl palmitate as a substrate.

\subsection{Effect of nitrogen sources on bacterial growth and lipase production}

The effect nitrogen sources on the bacterial growth and lipase production of L. garvieae strain L49 was studied by cultivating the bacteria in the medium containing various nitrogen sources $\left(\mathrm{NH}_{4}\right)_{2} \mathrm{SO}_{4}$, peptone and urea) and $2 \%$ olive oil. Overnight bacterial culture $\left(\mathrm{OD}_{600}=0.5\right)$ were inoculated to $500 \mathrm{~mL}$ flasks containing $100 \mathrm{~mL}$ of production medium and incubated at $37^{\circ} \mathrm{C}$ on shaker incubator $150 \mathrm{rpm}$. The bacterial growth and lipase production were monitored every 4 hours.

\subsection{Effect of vegetable oil concentration on bacterial growth and lipase production}

The effect of vegetable oil concentration on the bacterial growth and lipase production of L. garvieae strain L49 was studied by cultivating the bacteria in the medium containing various concentration of vegetable oil $(1,2,3,5 \% \mathrm{v} / \mathrm{v})$ as sole carbon source. The bacterial cell cultivated in medium without the addition of vegetable oil, as a control. Overnight bacterial culture $\left(\mathrm{OD}_{600}=0.5\right)$ were inoculated to $500 \mathrm{~mL}$ flasks containing 100 $\mathrm{mL}$ of production medium and incubated at $37^{\circ} \mathrm{C}$ on shaker incubator $150 \mathrm{rpm}$. The bacterial growth and lipase production were monitored every 4 hours.

\subsection{Ammonium sulfate precipitation}

Bacterial cells were grown for 20 hours in mineral medium containing $\left.\mathrm{NH}_{4}\right)_{2} \mathrm{SO}_{4}$ and olive oil as sole nitrogen and carbon source. Bacterial culture was centrifuged at $8000 \mathrm{rpm}$ for $20 \mathrm{~min}$ at $4{ }^{\circ} \mathrm{C}$. Cell free supernatant was saturated gradually with (0$40 \%),(40-60) \%,(60-80) \%$ ammonium sulfate, with continuous stirring at $4^{\circ} \mathrm{C}$ followed by centrifugation at $10,000 \mathrm{rpm}$ for 20 minutes. Ammonium sulfate fraction was dialyzed against $50 \mathrm{mM}$ Tris-Cl buffer ( $\mathrm{pH} 8.0$ ) for 6 hours at $4^{\circ} \mathrm{C}$ in a celophan dialysis bag. The concentrated enzyme after dialysis was determined its lipase activity and protein content. Total protein was estimated by using Bradford method [8]. Bovine serum albumin (BSA) was used as standard protein.

\subsection{Lipolytic assay}

Determination of enzyme activity was carried out according to Tripathi et al. [9] with a slight modification. The reaction mixture consisted of 100 $\mu \mathrm{L}$ crude extract, $800 \mu \mathrm{L}$ of $0.05 \mathrm{M}$ Tris buffer $(\mathrm{pH}$ 8 ) and $100 \mu \mathrm{L}$ of substrate (0.01 $\mathrm{M}$ in isopropanol), was incubated at $37^{\circ} \mathrm{C}$ for 15 minutes. Reaction was stop by adding $250 \mu \mathrm{L}$ of $0.1 \mathrm{M} \mathrm{Na}_{2} \mathrm{CO}_{3}$. The reaction mixture was centrifuged at $11,000 \mathrm{rpm}$ for $15 \mathrm{~min}$ and the absorbance was measured at 410 $\mathrm{nm}$. One unit of lipase activity was defined as the amount of enzyme which liberated $1 \mu \mathrm{mol}$ of $p$ nitrophenol per minute under standard assay conditions.

\subsection{SDS-PAGE and zymography analysis}

Protein analysis of lipase was performed by SDSPAGE and zymography analysis. For the SDSPAGE, separating gel (12.5\%) was prepared by mixing of $3.125 \mathrm{~mL}$ of Acrylamide, $1.875 \mathrm{~mL}$ Tris buffer (pH 8), $0.1 \mathrm{~mL}$ SDS 10\%, $2.5 \mathrm{~mL}$ aquadest, $0.1 \mathrm{~mL}$ TEMED and $0.1 \mathrm{~mL}$ ammonium persulfate. The stacking gel (4\%) was prepared by mixing of $1.0 \mathrm{~mL}$ acrylamide, $0.38 \mathrm{~mL}$ Tris buffer $(\mathrm{pH} \mathrm{6.8)}$, $0.03 \mathrm{~mL}$ SDS 10\%, $1.1 \mathrm{~mL}$ aquadest, $0.06 \mathrm{~mL}$ TEMED, and $0.08 \mathrm{~mL}$ ammonium persulfate.

In the zymography analysis, $12.5 \%$ separating gel and $4 \%$ stacking gel was prepared, then the samples were loaded along with the loading buffer to the stacking gel and run at $50 \mathrm{mv}$, the gel was taken 
and incubated in $0.05 \mathrm{M}$ Tris- $\mathrm{Cl}(\mathrm{pH} 8)$ containing $1 \%$ Triton-X for 30 minutes at $25{ }^{0} \mathrm{C}$ followed by $20 \%$ isopropanol and distilled water for 20 minutes. The gel was then incubated into a working buffer at $30{ }^{\circ} \mathrm{C}$ for 30 minutes to 12 hours until the clear zone was observed on the gel. The working buffer used consisted of $1.5 \%(\mathrm{v} / \mathrm{v})$ olive oil as substrate and $0.1 \%$ congo red indicator $(\mathrm{w} / \mathrm{v})$ emulsified in 0.05 M Tris-Cl (pH 8).

\section{RESULT AND DISCUSSION}

\subsection{Effect of vegetable oils on bacterial growth and lipase production}

Optimization of growth and enzyme production of an microorganisms from natural environment is often needed for industrial application. The mayor factor for the expression lipase activity has been reported as the carbon source, since lipases are inducible enzymes. Lipidic carbon sources seem to be generally essential for producing high lipase yield. However, a few researchers have obtained good yield in the absence of fats and oils [6]. In this present study, the effect of vegetable oils on bacterial growth and lipase production of $L$. garvieae were studied by cultivating the bacterial cells in the mineral medium containing various vegetable oils (olive oil, mustard oil, coconut oil, and sunflower oil). In this study, lipase production

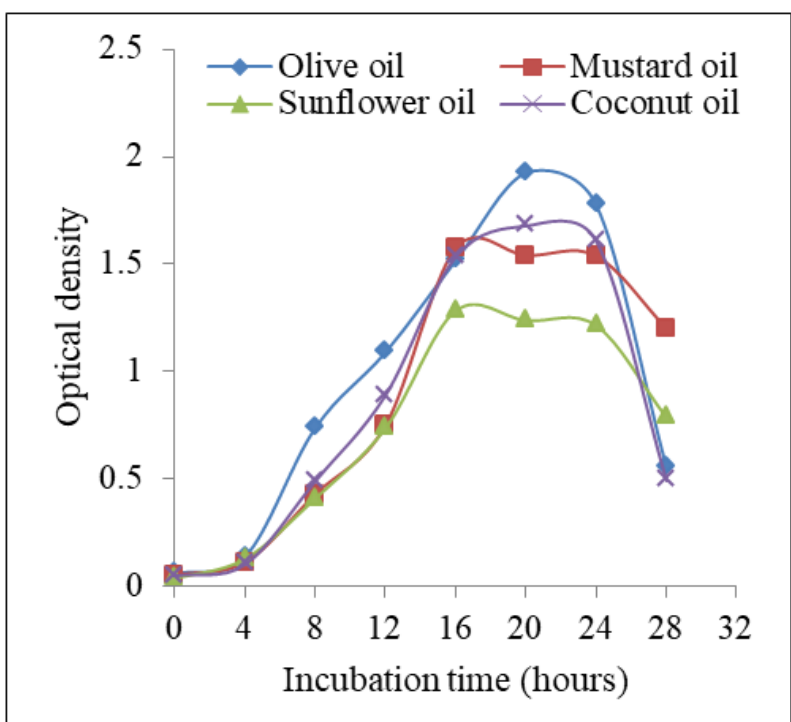

Figure 1. Effect of vegetable oils on bacterial growth.

\subsection{Effect of nitrogen sources on bacterial growth and lipase production}

Effect of nitrogen sources on bacterial growth and lipase production of L.garvieae was studied by cultivating bacterial cells in the mineral medium is expressed as the activity of the produced lipase. The data presented in the graphs are based on a triplicate measurement.

After studying the effect of four vegetable oils as carbon source on growth and lipase production of the bacterial strain, it was obvious that the vegetable oils used provided the good growth and lipase production of L.garvieae, as revealed in figure 1 and figure 2. Even though, olive oil had a great inductive effect on bacterial productivity. The lipase activity of $60.885 \mathrm{U} / \mathrm{mL}$ produced by L. garvieae after 20 hours bacterial cultivation in the medium containing $2 \%$ olive oil, as shown in the graph in figure 2 . The lipase activity was produced optimally at the beginning of stationary phase and decreased in a late stationary phase. The decreasing of lipase activity may be due to the presence of proteases in the culture media. Other bacteria Staphylococcus warneri showed the highest lipase production at the beginning of the stationary phase after 24 hours [9]. According to Zarevúcka (2012), the carbon source is the major factor for the expression of lipase activity, since lipases are inducible enzymes. These enzymes are generally produced in the presence of a lipid such as oil or triacylglycerol or any other inductor, such as fatty acids, hydrolysable esters, Tweens, bile salts, and glycerol. Lipidic carbon sources seem to be essential for obtaining a high lipase yield [10].

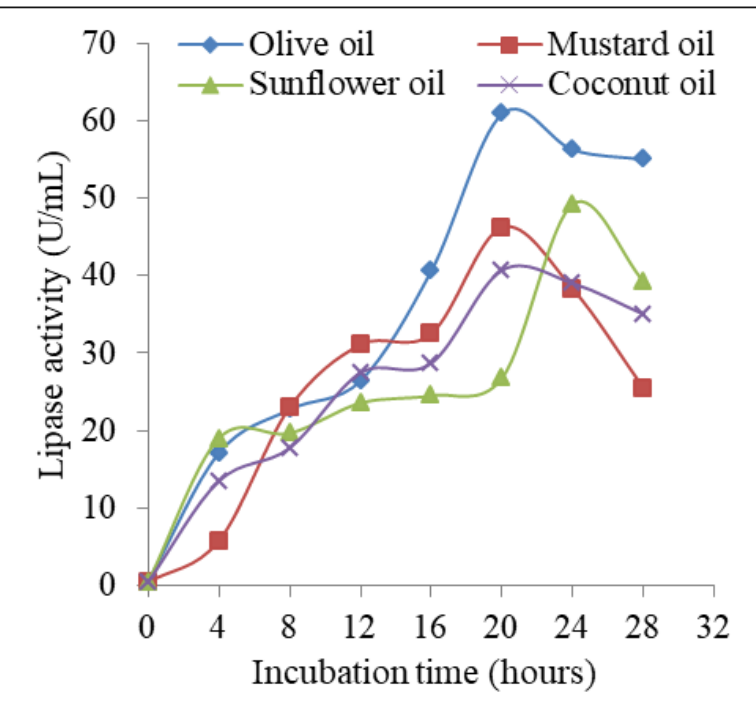

Figure 2. Effect of vegetable oils on lipase activity.

containing $2 \%$ olive oil as sole carbon source and varied nitrogen source. The result showed peptone, ammonium sulfate, and urea were good nitrogen sources for bacterial cells growth (figure 3.) and lipase production (figure 4.). However, peptone was the best nitrogen source for bacterial growth compared with ammonium sulfate and urea. The 
crude extract from 16-24 hours cell culture had lipase activity of 54.032 - $60.955 \mathrm{U} / \mathrm{mL}$. Generally, microorganisms provide high yields of lipase when organic nitrogen sources are used, such as peptone

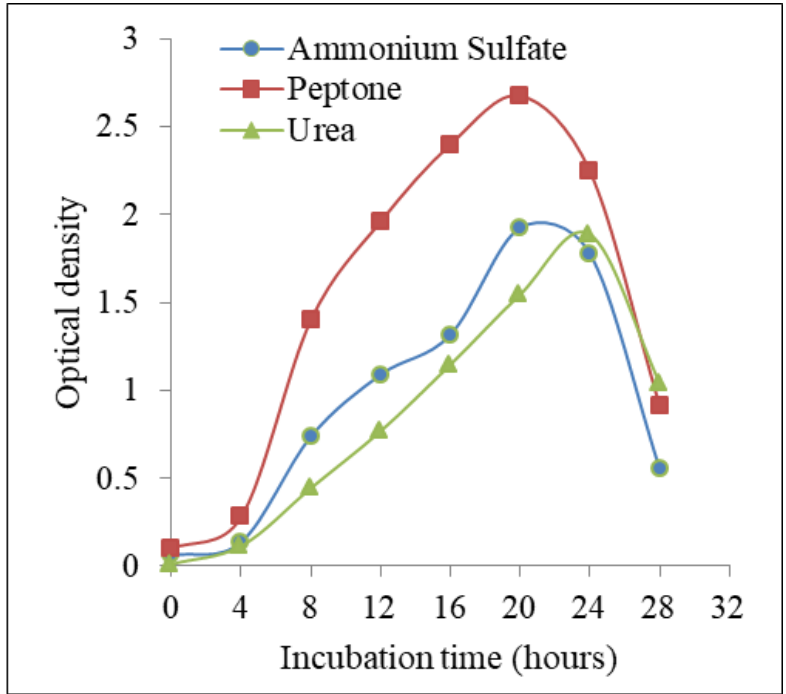

Figure 3. Effect of nitrogen sources on bacterial growth.

\subsection{Effect of olive oil concentration on lipase production}

Lipidic carbon sources seem to be generally essential for producing high lipase yield. However, a few researchers have obtained good yield in the absence of fats and oils [6]. Lipidic carbon sources such as triacylglycerol, fatty acid and glycerol serves as inducers for lipase production. Olive oil with high contents of of oleic acid is a well-known inducer for the lipase production by many bacterial and fungal strains [12]. In this study, olive oil had a great inductive effect on lipase productivity of $L$. and yeast extract. Similarly inorganic nitrogen sources ammonium sulfate and ammonium chloride enhanced lipase production of Pseudomonas gessardii isolated from oil spilled soil [11].

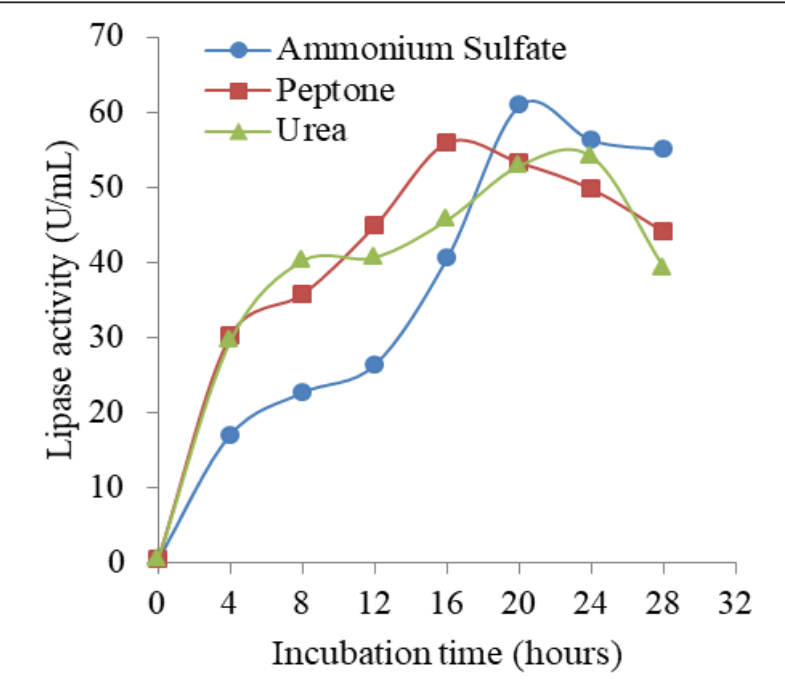

Figure 4. Effect of nitrogen sources on lipase activity.

garvieae. It was observed that the addition of $1 \%$ olive oil in medium improved the lipase activity by $135 \%$ compared to without olive oil in the medium. However, further increasing in oil concentration of $1 \%$ to $2 \%$ gave a slight increase in lipase activity. Crude extract with lipase activity of 56.790 $66.571 \mathrm{U} / \mathrm{mL}$ were produced by $L$. garvieae when it was cultivated in medium containing $1-5 \%$ olive oil, as shown in figure 5.

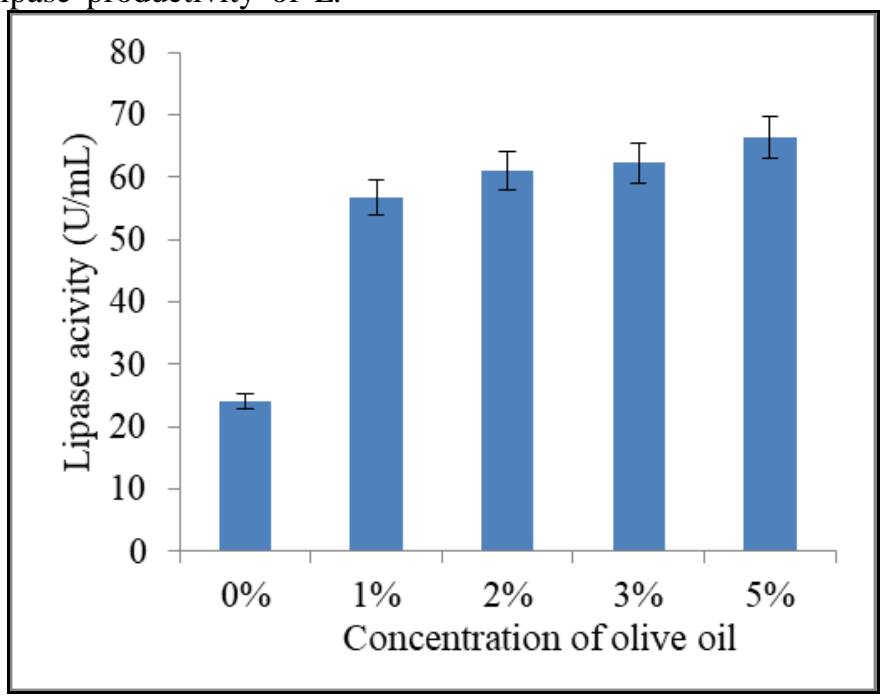

Figure 5. Effect of olive oil concentration on lipase activity. 


\subsection{Ammonium sulfate precipitation}

Partial purified of crude enzyme was obtained by precipitation with $0-80 \%$ ammonium sulphate fractionation. Data listed in table 1. explained that the lipase from $L$. garvieae is distributed in the fraction of ammonium sulfate $40 \%, 40-60 \%$ and $60-80 \%$ with the purification fold of $12.477,10.605$ and 11.668 respectively. Ammonium sulfate fractionation was also carried out by other researchers as an initial step in purifying enzymes, such as an extracellular lipase from Microbacterium sp. was purified by $0-70 \%$ ammonium sulfate [9], lipase from $P$. aeruginosa was precipitated by $30-90 \%$ amonnium sulfate [13].

Table 1. Summary of ammonium sulfate precipitation.

\begin{tabular}{cccccc}
\hline $\begin{array}{c}\left(\mathrm{NH}_{4}\right)_{2} \mathrm{SO}_{4} \\
\text { saturated }\end{array}$ & $\begin{array}{c}\text { Total Activity } \\
(\mathrm{U})\end{array}$ & $\begin{array}{c}\text { Total Protein } \\
(\mathrm{mg})\end{array}$ & $\begin{array}{c}\text { Specific activity } \\
(\mathrm{U} / \mathrm{mg})\end{array}$ & Yield $(\%)$ & $\begin{array}{c}\text { Purification } \\
(\text { fold })\end{array}$ \\
\hline Crude extract & 329.523 & 0.747 & 441.129 & 100 & 1 \\
$40 \%$ & 121.095 & 0.022 & 5504.318 & 36.748 & 12.477 \\
$40-60 \%$ & 86.085 & 0.018 & 4678.532 & 26.124 & 10.605 \\
$60-80 \%$ & 66.914 & 0,013 & 5147.230 & 20.306 & 11.668 \\
\hline
\end{tabular}

\subsection{SDS-PAGE and Zymography analysis}

Zymography is an electrophoretic technique based on SDS PAGE used for determination of enzyme or protein presence in the solution. This technique can be widely used for detection of lipase in crude as well as purified forms [14]. Electrophoresis of L.garvieae lipase on $12 \%$ SDS-PAGE for observation amount of purity enzyme during ammonium sulfate precipitation stages. The protein enzyme is shown as protein bands (rectangular marked) on the electrophoregram, as presented at figure 6 (a). The zymography analysis revealed a clear zone, indicating that reduced $\mathrm{pH}$ resulted in the release of fatty acids on the congo red indicator, and this result showed that the concentrated enzyme had lipase activity. There are at least 2 thicker protein bands on fraction $0-40 \%$ ammonium sulfate, as shown in figure 6 (b) lane 4. A), that had lipase activity, as evidenced by the formation of a clear zone, as shown in figure 6 (b) lane 4.

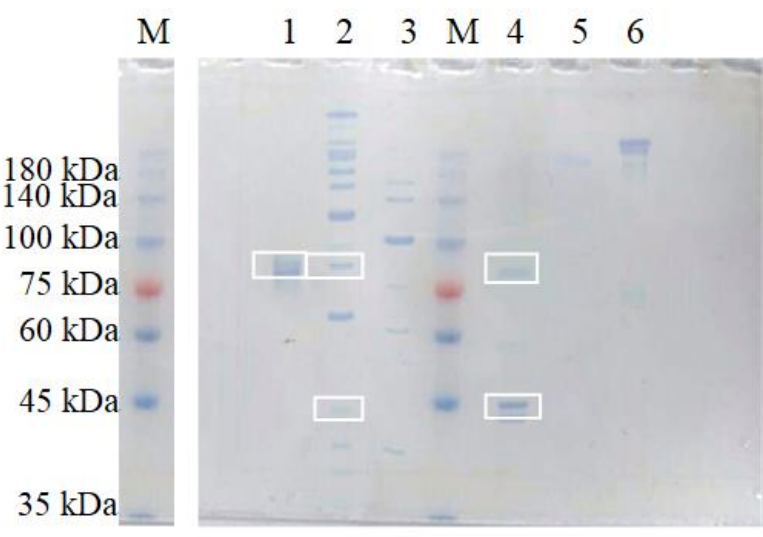

(a)

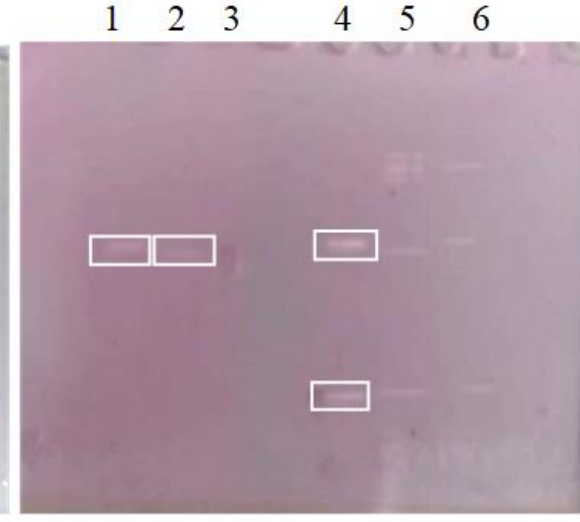

(b)

Figure 6. Electrophoregram (a), Zymography of enzyme protein L. Garvieae (b).

Lane 1: Lipase (positive control)

Lane 3: Crude extract (no inducer) M: Protein Marker
Lane 2: Crude extract (+ inducer)

Lane 4-6: Ammonium sulfate precipitation
Based on the results of SDS-PAGE and zymography, there were detected two protein enzymes which had lipase activity in hydrolyzing substrate olive oil, which can be seen as clear zone on zymogram, as presented in figure 6 (b) lane 4 . Therefore, it can be concluded that bacteria $L$. garvieae produced 2 types of lipases with molecular weight about 45 and $85 \mathrm{kDa}$. Other bacterial lipases have various molecular weight [15], e.g., Geobacillus thermodenitrificans AV-5 lipase: $50 \mathrm{kDa}$ [16], Geobacillus sp. EPT9 lipase: $44.9 \mathrm{kDa}$ [17], Chromobacter sp lipase: $44 \mathrm{kDa}$ [18], Janibacter sp. RO2 lipase: 44 kDa [19], Halobacillus sp lipase: $96 \mathrm{kDa}$ [20]. 


\section{CONCLUSION}

Lactococcus garvieae strain L49 used vegetable oils (olive oil, mustard oil, coconut oil, and sunflower oil) as sole carbon sources and inducers for lipase production. Olive oil had a great inductive effect on lipase productivity of $L$. garvieae, the addition of $1 \%$ olive oil in medium improved the lipase activity by $135 \%$ compared to without olive oil in the medium. However, further increasing in oil concentration of $1 \%$ to $2 \%$ gave a slight increase in lipase activity. Based on the results of SDS-PAGE and zymography analysis, $L$. garvieae strain L49 produced 2 types of lipases with molecular weight about 45 and $85 \mathrm{kDa}$.

\section{ACKNOWLEDGMENT}

The authors gratefully acknowledge DRPM Kementerian Riset, Teknologi dan Pendidikan Tinggi Indonesia for supporting this research.

\section{REFERENCES}

[1] Jooyandeh H, Kaur A, Minhas K S $2009 \mathrm{~J}$. Food Sci.Technol. 46(3) 181-9

[2] Bayoumi R A, El-louboudey S S, Sidkey N M and Abd-El-Rahman M A 2007 Journal of Applied Sciences Research $\mathbf{3}$ $1752-65$

[3] Franssen M C R,. Alessandrini L and Terraneo G 2005 Pure Appl. Chem. 77 273-9

[4] El-Hofi M, El-Tanboly E S \& Abd-Rabou N S 2011 Internet Journal of Food Safety 13 293-30I

[5] Andualema B and Gessesse A 2012 Biotechnology 11 100-18

[6] Sharma R, Cristi Y and Banerjee U C 2001 Biotechnology Advances 19 627-62

[7] Sumarsih S, Khurniyati M I, Pratama A, Puspaningsih NNT, 2018 Asian Jr. of Microbiol. Biotech. Env. Sc. 20 134-42.

[8] Bradford M M 1976 A Analytical Biochemistry 72 248-54

[9] Tripathi R, Singh J, Bharti R K, Thakur I S 2014 Energy Procedia 54518 - 29.

[10] Zarevúcka M 2012 Olive Oil as Inductor of Microbial Lipase in Borkou D (editor) Olive Oil: Constituents, Quality, Health Properties and Bioconversions DOI: 10.5772/1378 ISBN: 978-953-307-921-9 458

[11] Winayanuwattikun $\mathrm{P}$, Kaewpiboon $\mathrm{C}$, Piriyakananon K, Chulalaksananukul W, Yongvanich T and Svasti J 2011 Afr. J. Biotechnol. 10 1666-73.

[12] Wang D, Xu Y, Shan T 2008 Biochem. Eng. J. 41 30-37
[13] Borkar P S, Bodade R G, Rao S R, Khobragade C N 2009 Brazilian Journal of Microbiology 40 358-36

[14] Ghamari M, Alemzadeh I, Yazdi F T, Vossoughi M, Varidi M 2015 IJE TRANSACTIONS B: Applications $\mathbf{2 8}$ 1117-23

[15] Javed S, Azeem F, Hussain S, Rasul I, Siddique M H, Riaz M, Afzal M, Kouser A and Nadeem H 2017 Progress in Biophysics and Molecular Biology 132 23-34

[16] Christopher L P, Zambare V P, Zambare A, Kumar H and Malek L $2015 \mathrm{~J}$. Chem. Technol. Biotechnol. 90 2007-16.

[17] Zhu Y, Li H, Ni H, Xiao A, Li L and Cai H 2015 World J. Microbiol. Biotechnol. 31 295-306.

[18] Li X and Yu H 2012 African Journal of Microbiology Research 6(14) 3516-22

[19] Castilla A, Panizza P, Rodríguez D, Bonino L, Díaz P, Irazoqui G, Giordano S R 2017 Enzyme Microb. Technol. 98 86-95

[20] Li X and Yu H 2012 Afr. J. Biotechnol. 11 6327-34 